\title{
Ser Erdogan sig selv i Morsi?
}

\section{Justin Vela}

\section{Tyrkiets premierminister, Recep Tayyip Erdogan, er - som bekendt - kritisk over for det egyptiske militærs afsættelse af Egyptens første demokratisk valgte præsident, Mohammed Morsi fra Det Mus- limske Broderskab. Samtidig synes kuppet i Egyp- ten 3. juli at have tilskyndet Erdogan til at skærpe sin egen hårde politik $\mathrm{i}$ Tyrkiet}

Tyrkiet har oplevet fire militærkup i nyere tid - i 1960, 71, 80 og 97. Siden han kom til magten i 2002, har Erdogan og hans islamistiske Retfærdigheds- og Udviklingsparti (AKP) ført en konstant kampagne for at bringe det tyrkiske militær under fode. En milepæl blev nået i den kamp 5. august, da en særdomstol idømte 19 ud af 275 anklagede, herunder hærens tidligere stabschef, general Ilker Basbug, fængsel på livstid for angivelig at have deltaget $i$ en sammensværgelse for at fjerne AKP fra magten. Sammensværgelsen blev døbt Ergenekon.

Ergenekon-retssagen skulle angiveligt styrke demokratiske principper og bringe retfærdighed efter militærets og andre officielle organers forbrydelser i fortiden, men vil sand- synligvis 'forevige mistænksomhed og splittelse' i det tyrkiske samfund, noterede den britiske journalist, Andrew Finkel, der længe har boet i Istanbul, hvorfra han har rapporteret omfattende om Tyrkiet.

Beviser imod de arresterede, herunder journalister, var ofte uholdbare. Ifølge kritikere fremstod retssagen derfor mere som et instrument til at udradere kritikere.

Kuppet i Egypten gav sammen med protesterne i Gezi Parken i Istanbul Erdogan en mulighed for at fremstille sig selv som et potentielt offer, en taktik han tidligere har brugt til at styrke sin politiske position. "Det passer ham tydeligvis fint at se sig selv under en eller anden form for trussel", ifølge Finkel.

Selv om der ikke er konkrete bevi- 
ser for, at premierministeren eller regeringsfolk blandede sig i domstolens Ergenekon-domsafsigelser, syntes det egyptiske militærs aktioner at gøre Erdogan endnu mere ivrig efter at sikre civil kontrol med det tyrkiske militær, understregede Atilla Yesilada, politisk analytiker ved Istanbuls Global Source Partner.

Som en indikation på, hvordan det egyptiske kup rystede AKP, blev tre medlemmer af det tyrkiske militærs top, generalerne Bekir Kalyoncu og Hayri Kivrikoglu samt flådekommandør admiral Murat Bilgel tvunget til at trække sig tilbage, fremhævede Yesilada. Og en fjerde officer, luftstyrkernes kommandør, general Mehmet Erten, forventedes at trække sig inden seks måneder, ifølge avisen Hürriyet.

Rygter om, at demonstranter imod regeringen i det stille organiserede nye masseprotester i september, nærede Ankaras ønsker, ifølge Yesilada: "Egypten fik Erdogan til at fjerne de sidste navne, som var forbundet med Ergenekon".

Yesilada påpegede, at de pensionerede officerer arbejdede tæt sammen med dem, som var fundet skyldige.

Det faktum, at Vestens svar på kuppet især fra Tyrkiets nære allierede USA var relativt afdæmpede, "styrkede kun Erdogans frygt", tilføjede Yesilada.

Denne hans følelse af ubehag kom til fuldt udtryk 5. august, hvor myndighederne forbød selv familier til de anklagede at komme nær dom- huset i Silvri, en forstad til Istanbul, hvor dommene blev afsagt. Demonstranter, der støttede de anklagede, blev mødt med tåregas, gummikugler og vandkanoner, da de kom i konfrontation med uropoliti på en åben mark nær domhuset. Der ventes nu appeller imod dommene, der blev læst op under råb og piften.

Med et øje på de seneste begivenheder i Egypten vil den tyrkiske regering næppe slappe af, så længe den egyptiske proces fortsætter. Op til Ergenekon-dommene understregede Erdogan over for en folkemasse i Istanbul, at 'den nationale vilje', der er kommet til udtryk gennem dem, snarere end gennem pressen, sociale medier, kapitalmakedet eller 'terroriserede gader', vil afgøre Tyrkiets fremtid, skrev nyhedsbureauet Anadolu.

Alle Tyrkiets fire militærkup fandt sted i perioder med folkelig uro. På den baggrund har mindelser om erindringer om protesterne i Gezi Parken i juni, som medførte fem menneskers $\mathrm{d} \varnothing \mathrm{d}$, minimeret den officielle tolerance over for nye uroligheder.

\section{Tyrkisk-egyptisk strid}

Men mens Erdogans skarpe retorik kan styrke ham blandt sin mest konservative, religiøse hjemlige base, har hans fordømmelser af post-Morsi regeringen skadet de egyptisk-tyrkiske diplomatiske relationer alvorligt. 
Tyrkiets ambassadør i Egypten, Hüseyin Avni Botsali, var to gange indkaldt til officiel klage over Ankaras forsøg på at tage internationale initiativer til at bringe Morsi tilbage til magten. Erdogan selv blev ifølge rapporter forbudt at rejse gennem Egypten for at besøge Gaza Striben, hvilket længe har været hans ønske. Ifølge tyrkiske nyhedsbureauer advarede den egyptiske regering ham om, at han ikke vil blive vel modtaget i Egypten efter hans støtte til Det Muslimske Broderskab.

Ubekræftede rygter vil også vide, at tyrkiske borgere ikke længere kan få visa ved ankomsten til visse egyptiske havne.

I mellemtiden har sunnimuslimske lande i Golfen som Saudi-Arabi- en og Forenede Arabiske Emirater, der er indædte modstandere af Det Muslimske Broderskab, vist deres afsky for Tyrkiets højtråbende insisteren på, at Morsi vender tilbage til magten.

"De synes at have malet sig ind i noget af et hjørne", sagde Finkel om Ankaras nuværende position.

Men for ministerpræsidenten betyder det ikke meget. Med henvisning til Egypten, sagde Erdogan 6. august: "Tyrkiet har lidt meget under militærkup. Vi betalte prisen og $\varnothing n s k e r$ ikke, at vore (egyptiske) brødre kommer til at betale samme pris".

Justin Vela er free lance journalist med base $i$ Istanbul. 